\title{
Impacts of productive and recurrent public expenditure on economic growth in South Africa: An analysis using the autoregressive distributed lag - error correction model
}

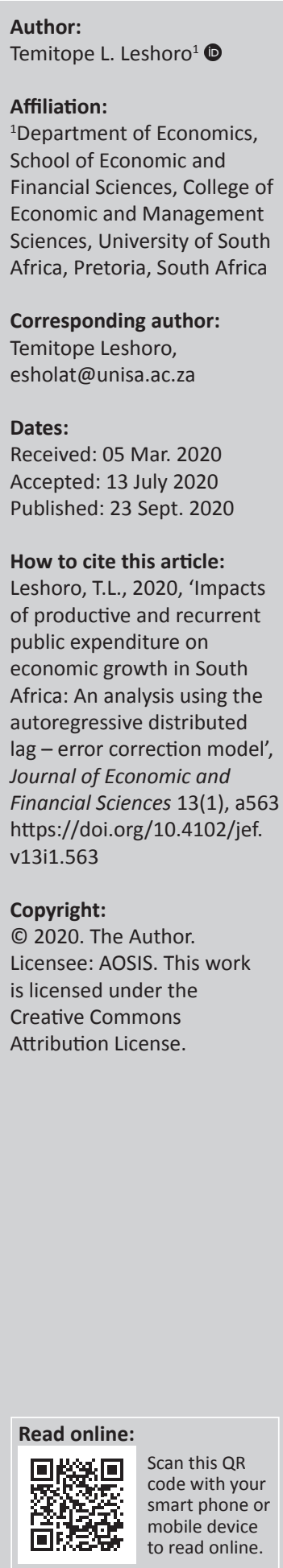

Orientation: The weak economic growth experienced by South Africa in the face of increased government spending is a concern.

Research purpose: Investigating different components of government spending helps to observe their relationships with economic growth and conclude whether or not government spending contributes to the lower economic growth.

Motivation for the study: Earlier studies in South Africa considered the effects of total government spending on economic growth; however, estimating this effect does not depict reality.

Research approach/design and method: This study used annual data from 1976 to 2017 to observe this relationship. The autoregressive distributed lag bounds-test approach to cointegration and the ARDL-based error correction method were adopted.

Main findings: The results showed that the two components of government spending positively affect economic growth in the short and long run. Government investment spending has a greater effect on economic growth in the long run than in the short run. The results showed that government consumption expenditure outweighs government investment expenditure, with the latter having lesser effect on economic growth.

Practical/managerial implications: This shows that increased government spending is not to be blamed for the slow growth in South Africa, supporting theory.

Contribution/value-add: Some studies did not disaggregate government spending into government investment and consumption spending in South Africa; and observed how each component affects economic growth; and other studies used econometric techniques that are different from the one used in the current study. This study therefore contributes to the ongoing discussion of the effect of government spending on economic growth.

Keywords: ARDL; consumption; economic growth; error correction method; disaggregated government spending; government expenditure; investment; South Africa.

\section{Introduction}

Efficient government spending is essential to boost any economy. Whilst government spending is a critical determinant of economic growth, its disaggregated component, which clearly highlights how each spending pattern affects economic growth, is more imperative as it shows the individual effect of each component. According to Easterly and Rebelo (1993:417-418), ‘[i]f you ask an economist to explain the growth performance of a particular country, he is likely to mention fiscal policy as being an important growth determinant'. However, aggregate government spending does not tell as much as the decomposed variable about the impact of government spending on economic growth. Yet the discussion of how much government spending impacts economic growth, especially in developing countries, continues to cause interest in empirical debate.

Government spending is disaggregated into two main components, namely, government investment (GI) spending, which is spending on infrastructure, health and education; and government consumption (GC) spending, which is made up of spending on defence, law and order and social grants. It is however unclear which of these two main components drives economic growth, especially in South Africa. By observing the trend in economic growth and 
government spending, the annual economic growth rate in the period $1993-2016$ was $2.91 \%$ on average, with an all-time high of $7.60 \%$ in the last quarter of 1994 and a low of $-6.10 \%$ in the first quarter of 2009 (Trading Economics 2016). On the other hand, GC spending, especially through social grants, increased following the end of apartheid.

However, over different quarters from 2015 to 2017, GC spending witnessed a negative growth, except in the second and last quarters of 2016, whilst GI spending increased during the same period (South African Reserve Bank [SARB] 2020). The economy shrank in the last quarter of 2016 compared with the increased growth of $0.4 \%$ in the third quarter; meanwhile, both government spending (GC and GI) increased in the same period. The overall growth in 2016 was $0.6 \%$, but it contracted by $0.3 \%$ quarter-on-quarter (SARB 2017) with a prediction of $0.8 \%$ growth for 2017 by the International Monetary Fund (IMF). Gross domestic product (GDP) declined by $0.7 \%$ in the second quarter of 2018 after it had shrunk by $2.6 \%$ in the first quarter (STATSSA 2018), leading to technical recession. Likewise, GC spending declined by $0.5 \%$ and $0.1 \%$ in the first two quarters of 2018, but GI spending witnessed an increase of $1 \%$ and $0.2 \%$ during the same period. Meanwhile, it is worth mentioning (although not the focus of this study) that the government size, measured as the ratio of government spending to gross domestic product, increased significantly from $12.97 \%$ in 1980 to $20.79 \%$ in 2016 (The Global Economy 2020).

Furthermore, previous findings have shown that there exist both positive and negative responses from economic growth as government spending increases and that the relationship between these variables is inconclusive and cannot be determined from the simple trend. Although many studies have investigated the effect of total (aggregate) government spending on economic growth in South Africa, some have observed only the GC component and others have disaggregated government spending into investment and consumption, adopting different techniques. In light of these discussions and the two main components of government spending, the goal of the present study is to contribute to the ongoing debate on the effect of government spending on economic growth.
The motivation for the study is that whilst total government spending has been increasing, the country has also experienced slow growth over the past few quarters with the recent technical recession in 2018. This study therefore seeks to observe, amongst other factors, the effect of disaggregated government spending on economic growth in order to examine which of the two components of government spending negatively impacts or positively contributes to economic growth. Therefore, the objective of the present study is to investigate disaggregated GC and GI spending in South Africa, whilst using different econometric techniques of autoregressive distributed lag (ARDL) and error correction model (ECM). This study will thus contribute to the ongoing discourse in this regard.

Figure 1 depicts the trend in both the economic growth and decomposed government expenditure on investment and consumption, on one hand, and their respective growth rates, on the other hand, in South Africa from 1976 to 2015. These growth rates as presented in Figure 1a show that there is a clear trend between economic growth and GC growth, but GI growth does not have a clear trend in relation to economic growth. However, as the focus of the present study, Figure $1 \mathrm{~b}$ shows the trend in the actual GI and GC spending against the growth rate of GDP per annum. There is clearly a positive trend amongst the three variables, with economic growth having the highest increase and GI expenditure the lowest. Economic growth has increased continuously from 1993, with a small decline at the onset of the global financial crisis in 2008. It, however, increased again, but at a slow rate. Government consumption expenditure increased steadily, whilst GI expenditure did not increase significantly over the entire period under revision but experienced a decline in the period 1982-2005 before picking up again. This shows the importance of disaggregating government spending in order to observe the effects of each component on economic growth.

The organisation of this article is as follows: the next section reviews empirical studies on government spending

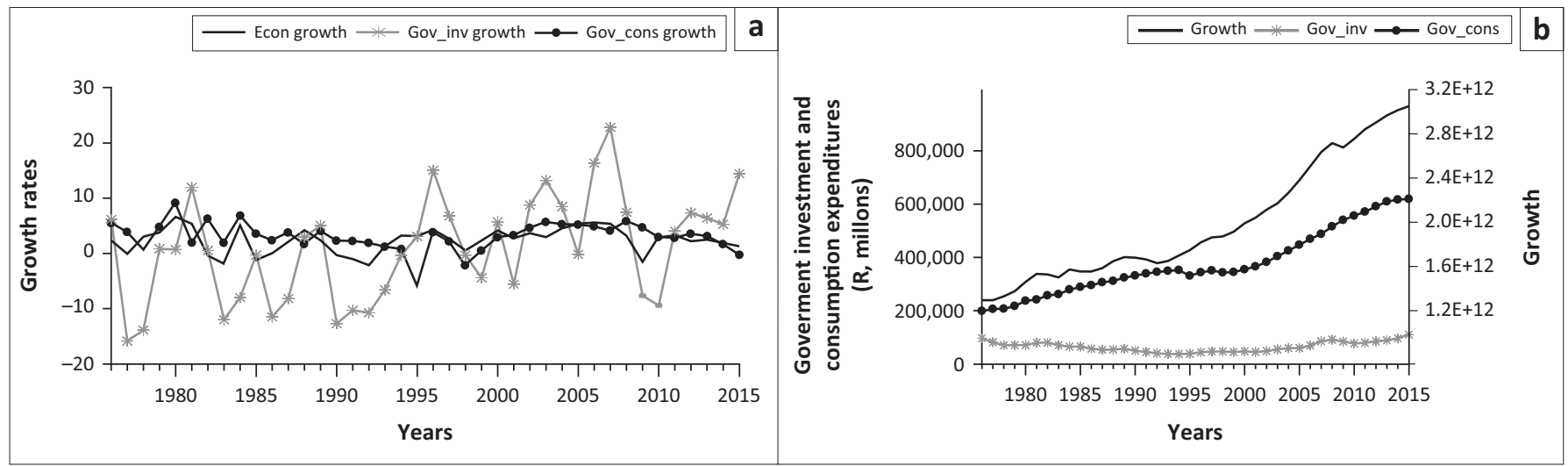

Source: South African Reserve Bank (SARB), 2019, Online database, viewed 13 March 2019, from https://www.resbank.co.za/Research/Statistics/Pages/OnlineDownloadFacility.aspx; and, The Global Economy, 2020, South Africa: Government spending, percent of GDP, viewed 03 Feb 2020, https://www.theglobaleconomy.com/South-Africa/government_size/

FIGURE 1: (a) Growth rates of gross domestic product (GDP), government investment and consumption spending: 1976-2015. (b) GDP growth, government investment and consumption spending: 1976-2015. 
and economic growth, followed by a discussion on data and methodology in the section 'Data and Methodology'. The 'Results' section discusses the empirical findings of the study followed by the conclusion and recommendations in the section 'Conclusion and policy recommendation'.

\section{Literature review}

This section briefly reviews the theoretical underpinnings and empirical studies that examined the impact of government spending and its various components on economic growth as well as the relationships found. Neither the theoretical nor empirical evidence clearly shows how government spending impacts economic growth. Barro (1991) argued that the impact of different components of government spending on output varies depending on the component being considered and that government spending would stimulate growth if it is investment-oriented whilst growth will be impeded by GC spending.

There are several theories that discuss the impact of government spending on economic growth. Amongst these theories, Keynes (1936) stated that an increase in government spending will stimulate the economy, thereby increasing output. When government spending increases through expansionary fiscal policy, production will increase, leading to increased aggregate demand and ultimately increased output. According to Ram (1986), expenditure on core areas of government has a positive effect on growth. On the other hand, the public choice theorists argued that as the size of a government increases, given the high distortionary effects of taxes, governmental inefficiencies will increase and government spending will thus have an adverse effect on economic growth (Christie 2012). Meanwhile, the neoclassical growth model argued that government spending does not have any significant impact on output. This growth model concluded that changes in government spending do not bring about any change in output, but changes in labour force, population growth (POPG) and changes in technology significantly affect output. However, none of the economic theories automatically provides evidence to conclude the impact of government spending on economic growth.

Whilst some empirical studies used aggregate government expenditure as a single variable, others believed that the variable should be decomposed into two components. Some researchers suggested that further disaggregation of each component should be analysed. However, what has become increasingly important is to categorise government spending into investment and consumption components (Ocran 2011). On the other hand, in terms of the expected relationship between government spending and economic growth, one strand of literature suggests that government spending would stimulate growth if it is investment-oriented and will inhibit it through GC spending (Akitoby et al. 2006; Barro 1991; Biswal, Dhawan \& Lee 1999; Bittencourt, Van Eyden \& Seleteng 2015; Bose, Hague \& Osborn 2007; Ndambiri et al. 2012). According to Blinder and Solow (2005), GC has a positive effect on the economy. Some researchers have further disaggregated GC spending into productive and unproductive (Devarajan, Swaroop \& Zou 1996).

So far, no consensus has been reached on the relationship between economic growth and government spending, mainly because of the disparities in the composition of government expenditures, data sample and model specification (Agell, Lindh \& Ohlsson 1997). Literature provides evidence of the positive and negative impacts of government spending on economic growth. Studies such as Biswal et al. (1999), Bose et al. (2007) and Mo (2007) have found that government spending has a positive impact on economic growth. However, Barro (1991) argued that increased government spending is normally associated with an increase in taxes, which leads to the distortion of economic incentives and discourages savings, investment and enterprise, thus hindering the economic growth. Supporting Barro (1991), studies such as D'Agostino, Dunne and Pieroni (2012), Ndambiri et al. (2012), Bittencourt et al. (2015) and Chirwa and Odhiambo (2016) also found that increased government spending has an adverse effect on economic growth.

Furthermore, Barro (1999), who investigated the determinants of economic growth for a panel of 100 countries, found a negative relationship between economic growth and government spending. The study used annual data over the period 1960-1995 and applied the results to the case of Chile. The study concluded that in order to have a high economic growth, GC and the fertility rate should be relatively low and investment should be encouraged. The study also pointed out that the inflation rate, schooling levels and international openness do not seem to explain the growth differentials.

Likewise, Ndambiri et al. (2012) explored a number of determinants of economic growth from a panel of 19 sub-Saharan African countries, using generalised method of moments (GMM) and annual data for the period 1982-2000. Their results showed that government spending, amongst other control variables, is significantly inversely related to economic growth. However, their study only included the final consumption expenditure of government without disaggregating GI. The study also failed to include the institutional variable, which could have captured possible political effects in sub-Saharan African countries on economic growth.

The study by Ocran (2011) used quarterly data from 1990 to 2004 to examine the effect of fiscal policy variables on economic growth in South Africa. The study decomposed government spending into investment and consumption spending and adopted the vector autoregressive (VAR) and impulse response function (IRF) techniques. The study found that both components of government spending boost economic growth, although the extent of the impact of GI spending is less than that of GC spending. Chirwa and Odhiambo (2016) also carried out a study to investigate the impact of total government spending on economic growth in South Africa, using the ARDL technique and annual time series data spanning over the period 
1970-2013. Their results showed that, amongst other variables, total government spending is a key and significant macroeconomic determinant of economic growth where government spending negatively impacts economic growth in the short and long run. By contrast, researchers such as Barro (1989) and Schaltegger and Torgler (2006) found the relationship between economic growth and government spending to be insignificant and inconclusive.

An earlier study by Bittencourt et al. (2015) investigated the effect of the inflation rate on the economic growth of Southern African Development Community (SADC) countries, using annual data spanning from 1980 to 2009. Although the inflation rate was the main explanatory variable, they used only the share of final GC to GDP and a proxy for democracy amongst other control variables. The study found that the inflation rate is detrimental to the growth in all the SADC countries and GC carries a negative and significant estimate. Meanwhile, the variable democracy presents a positive and significant effect on economic growth. On the other hand, Bose et al. (2007) evaluated the effects of aggregated capital expenditure and disaggregated GI on education in relation to economic growth in 30 developing countries. They used three-stage least squares (3SLs) to capture the endogeneity aspect of the model and confirm the robustness of the baseline results. They found that government expenditure on education is positively related to economic growth with longlasting effects and this is robust across aggregated and disaggregated government expenditure on education. Also, whilst aggregate capital (investment) expenditure is positively related to economic growth, aggregate current expenditure has no effect.

Furthermore, Ghosh and Gregorious (2008) used GMM to examine the effect of capital and current government spending on economic growth for 15 developing countries during the period 1972-1999. They further used expenditure on education and health to capture the capital spending, whilst expenditure on operations and maintenance capture the current spending. Contrary to common views, the study found that current spending has a positive and significant effect on economic growth, whilst capital spending is significantly negatively related to economic growth. This confirms the results of an earlier study conducted by Devarajan et al. (1996), who investigated the relationship between the composition of government spending and economic growth in 43 developing countries and found that productive spending could become unproductive if it is in excess.

Meanwhile, a recent study by Iwegbunam and Robinson (2019) observed the effects of aggregated government expenditure on various components of economic growth in South Africa, using quarterly data over the period 1970 Q1-2016 Q4 by adopting the cointegration technique and vector error correction model (VECM). The study did not consider disaggregate government expenditure, but observed the effect of total government expenditure on economic growth, which is different from what the current study observes. The results showed that there is a negative relationship between foreign direct investment and total government spending and between gross fixed capital formation and total government expenditure in South Africa. More results showed a positive relationship between total government expenditure and economic growth. As this study used total government expenditure, it was unable to explain the part of government expenditure that is positively related to economic growth in South Africa.

Thus, the contribution of this study is to examine the effects of disaggregated public spending on economic growth, using the autoregressive distributed lag - error correction model (ARDL-ECM) technique. This is different from earlier studies on South Africa reviewed above that rather observed the effect of total (or one component of) government spending on economic growth. This study therefore examines the effects and magnitudes of GI and GC spending on economic growth, thereby contributing to the ongoing discussion. The control variables used in this study are grouped into proximate and fundamental sources of economic growth. The variables include two measures of political variable, which capture democracy, seeing that the data sample covered more of the period of apartheid in South Africa; however, previous studies omitted this important variable.

\section{Data and methodology Discussion of data}

This study adopts annual data spanning the period 1976-2017, making 42 observations. The variables of interest are the real GDP, $(Y)$, provided by the World Bank; GC and GI expenditures, measured in billions of rand, obtained from the SARB database. Following from Barro (1990) and Ocran (2011), this study uses government spending, whilst disaggregating it into the two main components and observing their individual effects on economic growth. Based on the trend in government spending in South Africa, the expected relationship between economic growth and government expenditure is positive, although previous studies found mixed results regarding aggregate government spending. However, a positive relationship is generally expected between economic growth and GI expenditure (productive government spending on public goods) and between economic growth and GC expenditure (recurrent government spending) (Barro 1991; Christie 2012; Heller 2005; Ram 1986). The channel through which the relationship occurs is as explained in the theoretical review above.

There are several partial theories that discuss the role of different factors with an impact on economic growth. Two distinguished theories are the neoclassical growth model of Solow (1956) and the theory of endogenous growth by Romer (1986) and Lucas (1988). In addition, other developments considered the effect of non-economic factors on economic growth. These developments are grouped under the 'proximate' and 'fundamental' sources of economic growth. Whilst the proximate sources include capital accumulation, labour and technology, the fundamental sources are the legal 
and political systems, which include fiscal variables of government expenditure and taxation.

The control variables, which are divided into proximate and fundamental sources of economic growth, are rather standard in the literature. These variables are classified under labour, capital, institutional (or political), macroeconomic and human capital and are used in this study. All the control variables were obtained from the World Development Indicator (WDI) database of the World Bank, except for political right (PR), which was sourced from the Freedom House database.

The variable that captures labour is POPG. There are also inconclusive findings on the effect of POPG on economic growth. Some studies found a negative relationship between POPG and economic growth (Checherita-Westphal \& Rother 2012; Chirwa \& Odhiambo 2016), whilst others found a positive relationship (Radelet, Sachs \& Lee 2001). Labour is a factor of production and thus an increase in labour force resulting from an increase in population may cause total output and economic growth to increase. Also, an increase in the supply of labour as a result of increased population may cause wages to decline, thus leading to a decline in the cost of production, which will cause aggregate output to increase. Meanwhile, too much population hinders economic growth. Thus, either a positive or a negative relationship is expected between POPG and economic growth. Investment, measured as gross fixed capital formation (GFCF) is the variable that captures capital, measured in billions of rand; it is expected to positively affect economic activity. Investment is a component of aggregate demand; therefore, an increase in investment will boost aggregate demand and economic growth.

The institutional (or political) variable used in this study is the PR and a dummy for apartheid was used to check for robustness. Political rights are the rights used to protect the freedom of an individual from the infringements of government, private individuals and social organisations. Political right is measured on a scale of $1-7$, with 1 representing the highest degree of freedom and 7 the lowest. This variable also captures the effect of apartheid periods, which shows whether the country was free, partly free or not free. It is expected that the more the rights of individuals are protected (or the more freedom they possess), the lower the PR scale and the faster the economy grows. Thus, PR is expected to carry a negative sign. A dummy variable was used to capture the apartheid period in order to test for robustness. This variable captures the possible structural effect of the apartheid (1976-1994) and post-apartheid (1995-2017) regimes. As the apartheid period carries 1 , it means that the variable D_AP is expected to be negative, implying that the period of apartheid inversely affected economic growth.

The inflation rate (INF), which measures macroeconomic stability (Barro 2003), is an important macroeconomic variable that determines economic growth. Although many studies have found that the INF negatively affects economic growth (Bittencourt et al. 2015; Chirwa \& Odhiambo 2016), it exhibits threshold effects (Khan \& Senhadji 2001; Leshoro 2012; Phiri 2010). Thus, the a priori expectation is either a positive or a negative relationship between INF rate and economic growth. The rise in the price of goods and services (INF) affects the whole economy and thus the economic growth because real GDP is adjusted for INF.

Lastly, an economic growth model is not complete without including the human capital variable, which accounts for the role of education (human capital [HC]). The variable used in this study is the gross enrolment ratio of primary schools, defined as the total enrolment in primary education (regardless of age) expressed as a percentage of the population of official primary education age. Primary enrolment was used because data on secondary and tertiary enrolments are incomplete. The relationship between human capital and economic growth is also inconclusive. Whilst some studies have found a positive relationship (Barro 2003; Chirwa \& Odhiambo 2016), other studies have found a negative one (Hamilton \& Monteagudo 1998; Oluwatobi \& Ogunrinola 2011). Human capital can also be seen as a factor of production (Mincer 1984). Increase in human capital is a form of investment in the education of the workforce. An increase in the expansion of skills and education of the population will lead to higher employability and, thus, higher earning of the people. This will increase consumer spending and boost the economy. However, in situations whereby education does

TABLE 1: Descriptive statistics: 1976-2017.

\begin{tabular}{|c|c|c|c|c|c|c|c|}
\hline Statistics & $Y$ & GFCF & INF & GC & GI & POPG & $\mathrm{HC}$ \\
\hline Mean & $2.01 E+12$ & $3.50 E+11$ & 54.62786 & 387546.3 & 66326.38 & 42316820 & 97.02123 \\
\hline Median & $1.80 \mathrm{E}+12$ & $2.78 \mathrm{E}+11$ & 48.57912 & 347114.5 & 64746.00 & 43277772 & 102.0792 \\
\hline Maximum & $3.12 \mathrm{E}+12$ & $6.40 \mathrm{E}+11$ & 146.0537 & 633445.0 & 109084.0 & 56717156 & 114.4039 \\
\hline Minimum & $1.23 E+12$ & $1.97 \mathrm{E}+11$ & 4.074475 & 198204.0 & 36930.00 & 26904349 & 76.14064 \\
\hline Std. Dev. & $6.05 E+11$ & $1.52 \mathrm{E}+11$ & 42.37290 & 132175.9 & 20589.25 & 8978183.0 & 12.28209 \\
\hline Skewness & 0.583623 & 0.829912 & 0.532270 & 0.554582 & 0.367386 & -0.135348 & -0.547246 \\
\hline Kurtosis & 1.906847 & 2.034220 & 2.154821 & 2.135980 & 2.062540 & 1.777600 & 1.928259 \\
\hline Jarque-Bera & 4.475533 & 6.453553 & 3.233255 & 3.459354 & 2.482760 & 2.743191 & 4.106448 \\
\hline Probability & 0.106697 & 0.039685 & 0.198567 & 0.177342 & 0.288985 & 0.253702 & 0.128321 \\
\hline Sum & $8.43 E+13$ & $1.47 \mathrm{E}+13$ & 2294.370 & 16276946 & 2785708 & $1.78 \mathrm{E}+09$ & 4074.892 \\
\hline Sum Sq. Dev. & $1.50 E+25$ & $9.43 E+23$ & 73613.97 & $7.16 \mathrm{E}+11$ & $1.74 \mathrm{E}+10$ & $3.30 E+15$ & 6184.835 \\
\hline Observations & 42 & 42 & 42 & 42 & 42 & 42 & 42 \\
\hline
\end{tabular}

GC, government consumption; GI, government investment; INF, inflation; GFCF, gross fixed capital formation; HC, human capital; POPG, population growth. 
not match the level of employment, an increased human capital will negatively affect the economy. Therefore, either a positive or a negative relationship is expected between human capital and economic growth.

Table 1 shows the descriptive statistical analysis of the variables. During the period of study, investment, GFCF, exhibited higher average, median, maximum and minimum values than output, Y. On average, government spent more on consumption than on investment, whilst the average population stood at over 42 million. Likewise, the maximum and minimum government spending are higher for consumption than for investment. The average human capital was over $97 \%$, which means that the majority of primary school learners were enrolled in primary school. Whilst the minimum and maximum enrolments were $76 \%$ and over $100 \%$, respectively, the rate at which the enrolment rate differs from its mean was $12 \%$. On average, the price of the basket of goods and services was $55 \%$.

Furthermore, kurtosis measures the sharpness (peak) or the tail of a probability distribution, with a value of 3 , and all the variables are below this peak imply lighter tails and no outliers. Investment is the only variable that is not normally distributed as the null hypothesis, based on the Jarque-Bera test, is rejected at $5 \%$ level of significance, whilst it is not rejected for other variables, indicating that these variables are normally distributed.

Table 2 displays the correlation probability of all the variables (the correlation probability for D_AP democracy variable is presented in Appendix 1). The variables of interest, GC (recurrent) spending and GI (productive) spending show a positive and statistically significant correlation with economic growth. The positive sign on these disaggregated government expenditure is as expected (Barro 1991; Christie 2012; Heller 2005). Other control variables also exhibit positive and statistically significant correlation with economic activity, with the exception of POPG and PR.

\section{Estimation techniques}

The model and the variables as earlier defined are:

$Y_{t}=f\left(G F C F_{t}, I N F_{t}, G C_{t}, G I_{t}, P O P G_{t}, H C_{t}, P R_{t}\right)$

[Eqn 1]

$Y_{t}=f\left(G F C F_{t}, I N F_{t}, G C_{t}, G I_{t}, P O P G_{t}, H C_{t}, D_{-} A P_{t}\right)$

$D \_A P=\left\{\begin{array}{l}1 \text { Apartheid Period From 1976-1994 } \\ 0 \text { Otherwise }\end{array}\right.$

Equation 1 was transformed to logarithms except POPG and democracy variables, thereby allowing the variables to be measured at the same level, whilst also avoiding outliers. The variables are as earlier defined. Therefore, the following model was estimated:

$\log Y_{t}=\beta_{0}+\beta_{1} \log G F C F_{t}+\beta_{2} \log I N F_{t}+\beta_{3} \log G C_{t}+$ $\beta_{4} \log \mathrm{GI}_{t}+\beta_{5} P O P \mathrm{G}_{t}+\beta_{6} \log \mathrm{HC} \mathrm{C}_{t}+\beta_{7} P R_{t}+\varepsilon_{t}$

[Eqn 3]

However, Equation 2 is used to test for robustness, whilst using a different proxy for institutional variable. The popular ARDL of the Bounds test approach developed by Pesaran, Shin and Smith (2001) is used to determine the short- and long-run relationships. The study also estimates the coefficients and effects of the long- and short-run dynamics of the variables of interest on economic growth. The ARDL approach is based on estimating the model by using the ordinary least square (OLS) method of a conditional unrestricted error correction model (UECM) for cointegration. One of the many advantages of the Bounds testing method of cointegration and the ARDL approach is that it is not compulsory to perform a stationarity test; it is nevertheless required that the variables should not be of order two, I(2). This technique is applicable where variables are purely $\mathrm{I}(1)$ or a combination of $\mathrm{I}(0)$ and $\mathrm{I}(1)$.

Thus, the study will first test all the variables for stationarity, using the augmented Dickey-Fuller (ADF) and Phillips-Perron (PP) tests of stationarity. This is to

TABLE 2: Correlation probability.

\begin{tabular}{|c|c|c|c|c|c|c|c|c|}
\hline Variable & $\log Y$ & $\operatorname{logGFCF}$ & $\log I N F$ & $\log G C$ & $\log G I$ & POPG & $\log \mathrm{HC}$ & PR \\
\hline \multirow[t]{2}{*}{$\log Y$} & 1.000000 & - & - & - & - & - & - & - \\
\hline & - & - & - & - & - & - & - & - \\
\hline \multirow[t]{2}{*}{$\log$ GFCF } & $0.918100 * * *$ & 1.000000 & - & - & - & - & - & - \\
\hline & 0.000000 & - & - & - & - & - & - & - \\
\hline \multirow[t]{2}{*}{$\log I N F$} & $0.926400 * * *$ & $0.715300 * * *$ & 1.000000 & - & - & - & - & - \\
\hline & 0.000000 & 0.000000 & - & - & - & - & - & - \\
\hline \multirow[t]{2}{*}{$\log G C$} & $0.979400 * * *$ & $0.842600 * * *$ & $0.954200 * * *$ & 1.000000 & - & - & - & - \\
\hline & 0.000000 & 0.000000 & 0.000000 & - & - & - & - & - \\
\hline \multirow[t]{2}{*}{$\log G I$} & $0.374100 * *$ & $0.679100 * * *$ & 0.011000 & $0.252200 * *$ & 1.000000 & - & - & - \\
\hline & 0.013500 & 0.000000 & 0.944200 & 0.102800 & - & - & - & - \\
\hline \multirow[t]{2}{*}{ POPG } & $-0.913500 * * *$ & $-0.786800 * * *$ & $-0.908100 * * *$ & $-0.873200 * * *$ & -0.192300 & 1.000000 & - & - \\
\hline & 0.000000 & 0.000000 & 0.000000 & 0.000000 & 0.216600 & - & - & - \\
\hline \multirow[t]{2}{*}{$\log \mathrm{HC}$} & $0.445600 * * *$ & 0.234789 & $0.653600 * * *$ & $0.481500 * * *$ & $-0.330600 * *$ & $-0.522500 * * *$ & 1.000000 & - \\
\hline & 0.002700 & 0.129600 & 0.000000 & 0.001100 & 0.030300 & 0.000300 & - & - \\
\hline \multirow[t]{2}{*}{ PR } & $-0.671100 * * *$ & $-0.550800 * * *$ & $-0.758200 * * *$ & $-0.616900 * * *$ & 0.046800 & $0.796300 * * *$ & $-0.701300 * * *$ & 1.000000 \\
\hline & 0.000000 & 0.000100 & 0.000000 & 0.000000 & 0.765800 & 0.000000 & 0.000000 & - \\
\hline
\end{tabular}

GC, government consumption; GI, government investment; POPG, population growth; PR, political right; HC, human capital; INF, inflation rate; GFCF, gross fixed capital formation. $*, 10 \%$; **, $5 \%$; ***, $1 \%$. 
determine the orders of integration of each variable, as ARDL is sensitive to $I(2)$ variables. Another advantage of the ARDL technique, besides its statistical properties, is that estimations can be carried out even in the presence of endogeneity of the explanatory variables. The problem of endogeneity is common in growth models because they include the lags of the dependent and explanatory variables. In addition, the ARDL technique is a powerful tool used to investigate short- and long-run cointegrating relationships amongst variables (Odhiambo 2015; Pesaran \& Shin 1999). Finally, this technique is efficient even for small samples, which is the case for this study.

The conditional ARDL economic growth model for Equation 3 is therefore expressed as:

$$
\begin{aligned}
& \Delta \log Y_{t}=\alpha_{0}+\sum_{i=1}^{n} \alpha_{1} \Delta \log Y_{t-i}+\sum_{i=0}^{n} \alpha_{2} \Delta \log G F C F_{t-i}+ \\
& \sum_{i=0}^{n} \alpha_{3} \Delta \log I N F_{t-i}+\sum_{i=0}^{n} \alpha_{4} \Delta \log G C_{t-i}+ \\
& \sum_{i=0}^{n} \alpha_{5} \Delta \log G I_{t-i}+\sum_{i=0}^{n} \alpha_{6} \Delta P O P G_{t-i}+\sum_{i=0}^{n} \alpha_{7} \Delta \log H C_{t-i}+ \\
& \sum_{i=0}^{n} \alpha_{8} \Delta P R_{t-i}+\beta_{1} \log Y_{t-1}+\beta_{2} \log G F C F_{t-1}+ \\
& \beta_{3} \log I N F_{t-1}+\beta_{4} \log G C_{t-i}+\beta_{5} \log G I_{t-1}+ \\
& \beta_{6} P O P G_{t-1}+\beta_{7} \log H C_{t-1}+\beta_{8} P R_{t-1}+\varepsilon_{t}
\end{aligned}
$$

In Equations 4-6, $\Delta$ represents the first difference; the short- and long-run elasticities are $\alpha_{1^{\prime}}, \ldots, \alpha_{8}$ and $\beta_{1^{\prime}}, \ldots, \beta_{8^{\prime}}$ respectively; and $\varepsilon_{t}$ is the error term.

The null hypothesis, which indicates the non-existence of a long-run relationship, is

$\mathrm{H}_{0}: \beta_{1}=\beta_{2}=\beta_{3}=\beta_{4}=\beta_{5}=\beta_{6}=\beta_{7}=\beta_{8}=0$

[Eqn 5]

against the alternative hypothesis of the existence of a long-run relationship

$\mathrm{H}_{1}: \beta_{1} \neq \beta_{2} \neq \beta_{3} \neq \beta_{4} \neq \beta_{5} \neq \beta_{6} \neq \beta_{7} \neq \beta_{8} \neq 0$.

[Eqn 6]

The F-test is used to determine if cointegration exists amongst the variables. The interpretation of the cointegration test is as follows: if the computed F-statistic lies between the upper and lower bounds at a chosen significant level, there is no decision on whether there is cointegration. If the F-statistic exceeds the upper bound, the null hypothesis of 'no co-integration' is rejected, and if it lies below the lower bound, the null hypothesis cannot be rejected. Pesaran et al. (2001) developed critical values for lower bound or stationary variables $\mathrm{I}(0)$ and the critical values for upper bound or variables integrated of order one, I(1).

If cointegration is found, the short- and long-run model of Equation 4 will be estimated, using the standard OLS. This will allow us to obtain the speed of adjustment of economic growth back to equilibrium as well as the short- and long-run coefficients. Thus, the ECM is expressed by re-parametering Equation 4 as follows:

$$
\begin{aligned}
& \Delta \log Y_{t}=\alpha_{0}+\sum_{i=1}^{n} \alpha_{1} \Delta \log \mathrm{Y}_{t-i}+\sum_{i=0}^{n} \alpha_{2} \Delta \log G F C F_{t-i}+ \\
& \sum_{i=0}^{n} \alpha_{3} \Delta \log I N F_{t-i}+\sum_{i=0}^{n} \alpha_{4} \Delta \log G C_{t-i}+\sum_{i=0}^{n} \Delta \log G I_{t-i}+ \\
& \sum_{i=0}^{n} \alpha_{6} \Delta P O P G_{t-i}+\sum_{i=0}^{n} \alpha_{7} \Delta \log H C_{t-i}+\sum_{i=0}^{n} \alpha_{8} \Delta P R_{t-i}+ \\
& \gamma E C T_{t-1}+\varepsilon_{t}
\end{aligned}
$$

[Eqn 7]

The coefficient of the error correction term (ECT), $\gamma$, measures the short-run speed of adjustment back to the long-run equilibrium. It shows how the economic growth deviates from the long-run equilibrium, but gradually returns to its long-run equilibrium path. Therefore, in order for the economy to adjust to equilibrium, the coefficient of the ECT must be less than 1, negative and statistically significant (Chirwa \& Odhiambo 2016). The ECT has a lag of

\begin{tabular}{|c|c|c|c|c|c|c|}
\hline \multirow[t]{2}{*}{ Variables } & \multirow[t]{2}{*}{ Model } & \multicolumn{2}{|c|}{ ADF test } & \multicolumn{2}{|c|}{ Phillips-Perron test } & \multirow[t]{2}{*}{ Decision } \\
\hline & & Levels & 1st Diff. & Levels & 1st Diff. & \\
\hline $\log Y_{t}$ & With Trend & -1.868 & $-4.294 * * *$ & 1.502 & $-4.161^{* *}$ & I(1) \\
\hline $\log G F C F_{t}$ & Without Trend & -0.615 & $-3.622 * * *$ & -0.027 & $-3.317^{* *}$ & I(1) \\
\hline $\log I N F_{t}$ & Without Trend & $-3.252 * *$ & N/A & $-4.560 * * *$ & N/A & $\mathrm{I}(0)$ \\
\hline $\log G C_{t}$ & With Trend & $-4.180 * * *$ & N/A & -1.922 & $-5.174 * * *$ & $\mathrm{I}(1)$ \\
\hline $\log G I_{t}$ & Without Trend & -1.457 & $-4.040 * * *$ & -0.927 & $-3.954 * * *$ & I(1) \\
\hline $\log H C_{t}$ & Without Trend & -1.115 & $-5.354 * * *$ & -1.410 & $-5.349 * * *$ & I(1) \\
\hline
\end{tabular}
1 , which shows the percentage of speed of adjustment from a shock in the previous period to the present period equilibrium (Mpatane \& Eita 2016).

\section{Ethical consideration}

Ethical approval to conduct the study was obtained from the Department of Economics' Ethics Review Committee, University of South Africa (Ethical Clearance Number: 2019 DE_03(SD)_Prof. Leshoro, 15 February 2019).

TABLE 3: Unit root test results.

ADF, Augmented Dickey-Fuller; GC, government consumption; GI, government investment; POPG, population growth; HC, human capital; INF, inflation rate; GFCF, gross fixed capital formation; Diff., difference; N/A, not applicable.

$*, 10 \% ; * *, 5 \% ; * * *, 1 \%$.

Test critical values: None $(1 \%-2.621 ; 5 \%-1.948 ; 10 \%-1.612)$; Without Trend $(1 \%-3.60 ; 5 \%-2.935 ; 10 \%-2.606)$; With Trend $(1 \%-4.199 ; 5 \%-3.524 ; 10 \%-3.193)$. 


\section{Results}

\section{Stationarity test results}

It is important to first determine the order of integration by testing the stationarity of all the variables, as the ARDL technique is sensitive to $\mathrm{I}(2)$ variables. Stationarity (unit root) tests are therefore carried out using the ADF and PP and the results are presented in Table 3. The results show that all the variables except $\log \mathrm{CPI}$ and POPG are integrated of order one, I(1), and become stationary after the first difference. As the results show that the variables have a mix of order of integration - that is, I(0) and I(1) ARDL is thus the most applicable cointegration technique.

\section{Autoregressive distributed lag bounds test for cointegration result}

Before testing for cointegration, it is essential to determine optimal lag. The maximum lag length as selected by Akaike information criterion (AIC) is 3 . This is based on the number of regressors included in the growth model. The optimal ARDL model therefore selected for the South African growth equation is $\operatorname{ARDL}(2,2,2,0,2,1,0,0)$. The next step is to observe whether cointegration exists amongst the variables. The cointegration test results reported in Tables 4 and 5 are based on 'Case II: Restricted intercept and no trend' of Pesaran et al. (2001), as chosen by the EViews software used. These results show that the null hypothesis of 'no cointegration' should be rejected because the F-statistics, 4.349 , lies above the upper bound, I(1), at all levels of significance. Thus, there exists a long-run relationship between economic growth and all the explanatory variables.

\section{Autoregressive distributed lag-based error correction model result}

Table 6 shows the short- and long-run relationships of the growth model for South Africa. Whilst panel 1 reports the short-run coefficients along with the ECT coefficient, panel 2 reports the long-run coefficients.

The results show that whilst GC (recurrent) and GI (productive) expenditures positively affect economic growth in the short and long run, variables, such as governance, proxied by PRs, INF and the role of education negatively affect economic growth in South Africa during the period observed. This implies that government spending is not one of the factors that negatively affect economic growth. Both

TABLE 4: Autoregressive distributed lag bounds test results.

\begin{tabular}{lcl}
\hline Test Statistic & Value & $\boldsymbol{k}$ \\
\hline$F$-statistic & $4.349^{* * *}$ & 7 \\
\hline
\end{tabular}

Null Hypothesis: No long run relationships exist. $k$ is the number of explanatory variables. $* * *, 1 \%$.

TABLE 5: Critical value bounds.

\begin{tabular}{lcc}
\hline Significance (\%) & I(0) Bound & I(1) Bound \\
\hline 10 & 1.92 & 2.89 \\
5 & 2.17 & 3.21 \\
2.5 & 2.43 & 3.51 \\
1 & 2.73 & 3.90 \\
\hline
\end{tabular}

components of government expenditure are statistically significant at all levels in the short run (panel 1) and they have the expected positive signs. At one period lag, GI expenditure shows a negative relationship in the short run.

If GI expenditure increases by $1 \%$, in the short run, economic growth will generally increase by $0.12 \%$. Meanwhile, a $1 \%$ increase in consumption expenditure will cause economic growth to increase by $0.2 \%$ in the short run. This corroborates the trend in GC spending shown in Figure 1b, where GC outweighs GI spending. The same pattern is seen in the long run where both expenditure components positively influence growth such that a per cent increase in consumption and investment expenditures will increase the economic growth by $0.4 \%$ and $0.3 \%$, respectively. This is in line with the previous studies by Ghosh and Gregorious (2008) on 15 developing countries and Ocran (2011) on South Africa, amongst others, using different time periods, variables and econometric techniques. In the short run and long run, government recurrent spending has a more positive effect on economic growth than government productive spending. This is also not surprising as government spends so much on social grants amongst other GC spending. This is not to say that government does not spend on investment; it simply does not spend as much on investment as on consumption.

The control variables are all statistically significant in the short run. Investment is economically and statistically significant only in the short run. A per cent increase in investment will cause economic growth to generally increase by $0.27 \%$ in the short run (panel 1 ). This confirms the expected positive relationship between investment and

TABLE 6: Long-run and short-run results.

\begin{tabular}{|c|c|c|c|}
\hline Variable & Coefficient & Std. error & $t$-statistic \\
\hline \multicolumn{4}{|c|}{ Panel 1: Short-run coefficients } \\
\hline$\Delta \log (\mathrm{Y})_{t-1}$ & $-0.514 * * *$ & 0.153 & -3.365 \\
\hline$\triangle \log (\mathrm{GFCF})$ & $0.141 * * *$ & 0.035 & 4.038 \\
\hline$\Delta \log (\mathrm{GFCF})_{t-1}$ & $0.125 * * *$ & 0.038 & 3.295 \\
\hline$\triangle \log (\mathrm{INF})$ & $0.218 * *$ & 0.092 & 2.361 \\
\hline$\Delta \log (\text { INF })_{t-1}$ & $-0.367 * * *$ & 0.091 & -4.016 \\
\hline$\Delta \log (\mathrm{GC})$ & $0.196 * * *$ & 0.069 & 2.832 \\
\hline$\Delta \log (\mathrm{GI})$ & $0.186 * * *$ & 0.037 & 4.999 \\
\hline$\Delta \log (\mathrm{GI})_{t-1}$ & $-0.066 * *$ & 0.026 & -2.564 \\
\hline$\Delta(\mathrm{POPG})$ & $0.079 * *$ & 0.033 & 2.426 \\
\hline$\Delta \log (\mathrm{HC})$ & $-0.137 * * *$ & 0.038 & -3.638 \\
\hline$\Delta(\mathrm{PR})$ & $-0.010 * * *$ & 0.003 & -3.286 \\
\hline $\mathrm{ECT}_{t-1}$ & $-0.591 * * *$ & 0.087 & -6.781 \\
\hline \multicolumn{4}{|c|}{ Panel 2: Long-run coefficients } \\
\hline $\log (\mathrm{GFCF})_{\mathrm{t}}$ & -0.063 & 0.105 & -0.596 \\
\hline $\log (\mathrm{INF})_{\mathrm{t}}$ & $0.111 *$ & 0.058 & 1.933 \\
\hline $\log (\mathrm{GC})$ & $0.356 * *$ & 0.149 & 2.399 \\
\hline $\log (G I)_{t}$ & $0.248 * * *$ & 0.065 & 3.825 \\
\hline$(P O P G)_{t}$ & -0.049 & 0.036 & -1.372 \\
\hline $\log (\mathrm{HC})_{\mathrm{t}}$ & $-0.231 * * *$ & 0.085 & -2.705 \\
\hline$(P R)_{t}$ & $-0.018 *$ & 0.011 & -1.707 \\
\hline$\underline{C_{t}}$ & $23.507 * * *$ & 1.800 & 13.055 \\
\hline \multicolumn{4}{|c|}{$\begin{array}{l}\text { ECT, error correction term; GC, government consumption; GI, government investment; } \\
\text { POPG, population growth; INF, inflation rate; GFCF, gross fixed capital formation; } \\
\text { HC, human capital. }\end{array}$} \\
\hline $\begin{array}{l}\text { Dependent var } \\
*, 10 \% ; * *, 5 \%\end{array}$ & & & \\
\hline
\end{tabular}


economic growth. Whilst INF is generally negatively related to economic growth in the short run, it is positively related to economic growth in the long run, however, only at a $10 \%$ level of significance. A per cent increase in INF will lead to about $0.11 \%$ increase in economic growth in the long run (panel 2). Given that the a priori expectation of INF is either positive or negative based on the threshold effects, the positive impact of INF on economic growth shows that in the long run INF is not high enough to be detrimental to economic growth in South Africa (Leshoro \& Kollamparambil 2017; Phiri 2010). Hence, the weak economic growth cannot be attributed to high INF in South Africa based on the findings of this study.

On the other hand, given the a priori expectation of either positive or negative relationship between POPG and economic growth, POPG was found to be positively related to economic growth in the short run, but this changed to a negative and statistically insignificant relationship in the long run. Positive and statistically significant POPG in the short run implies that South Africa's economic growth will increase by $0.08 \%$ given a $1 \%$ increase in POPG. This shows that in the short run, as population increases, labour force also increases, thereby increasing the production and economic growth. However, a negative relationship was found by Chirwa and Odhiambo (2016) for South Africa in both the long and short run but at a $10 \%$ level of significance.

Not surprising is human capital, HC, that was found to be negatively and statistically significantly related to economic

TABLE 7: Diagnostic tests.

\begin{tabular}{llcc}
\hline Test & Null hypothesis & \multicolumn{2}{c}{ Probability } \\
\hline Normality Test: Jarque-Bera & $\begin{array}{l}\text { Error term is normally } \\
\text { distributed }\end{array}$ & 0.331 & 0.848 \\
$\begin{array}{l}\text { Serial Correlation LM Tests: } \\
\text { Breusch-Godfrey, F(2,22) }\end{array}$ & No serial correlation & 2.129 & 0.143 \\
$\begin{array}{l}\text { Heteroscedasticity Test: } \\
\text { Breusch-Pagan-Godfrey, }\end{array}$ & Homoscedasticity & 1.587 & 0.149 \\
$\begin{array}{l}\text { F(16,24) } \\
\begin{array}{l}\text { Ramsey RESET Test: } \\
\text { Functional Form }(1,23)\end{array}\end{array}$ & Stable model & & \\
\hline
\end{tabular}

growth in the long and short run. This is consistent with earlier studies that found a negative relationship between human capital and economic growth where they used total school enrolment (Hamilton \& Monteagudo 1998; Oluwatobi \& Ogunrinola 2011). Likewise, the result is in line with the study conducted by Bittencourt et al. (2015) who used the number of teachers per 100 pupils and found a negative relationship between education and economic growth, although not significant.

Thus, a 1\% increase in primary school enrolment will cause economic growth to decline by $0.14 \%$ and $0.23 \%$ in the short run and the long run, respectively. There is a greater impact of school enrolment on economic growth in the long run than in the short run. The possible reason for the negative effect of primary school enrolment on economic growth is the variable measurement used, which is the gross enrolment ratio of primary schools. Primary school enrolment is not the highest level of educational attainment; hence, it might not have a huge impact to positively affect economic growth. Besides, there is the possibility of dropouts before reaching secondary and tertiary levels, thus they are not able to complete their education to the point where their skills could be beneficial to the economy and they assist in avoiding the structural unemployment problem that South Africa is facing (Setiloane 2017). Also, primary education is no longer an indicator of job requirements that will benefit the economy.

As expected, the democracy variable, PR, has a negative and highly statistically significant effect on economic growth. This shows that the lower the PRs scale, the more the rights of individuals are protected and the faster the economy grows. The coefficient of the ECT is negative, less than 1 as expected and statistically significant at all levels, implying the adjustment back to the long-run equilibrium. The ECT value shows that about $0.6 \%$ of disequilibrium is corrected annually. This suggests that if economic growth deviates from its long-run

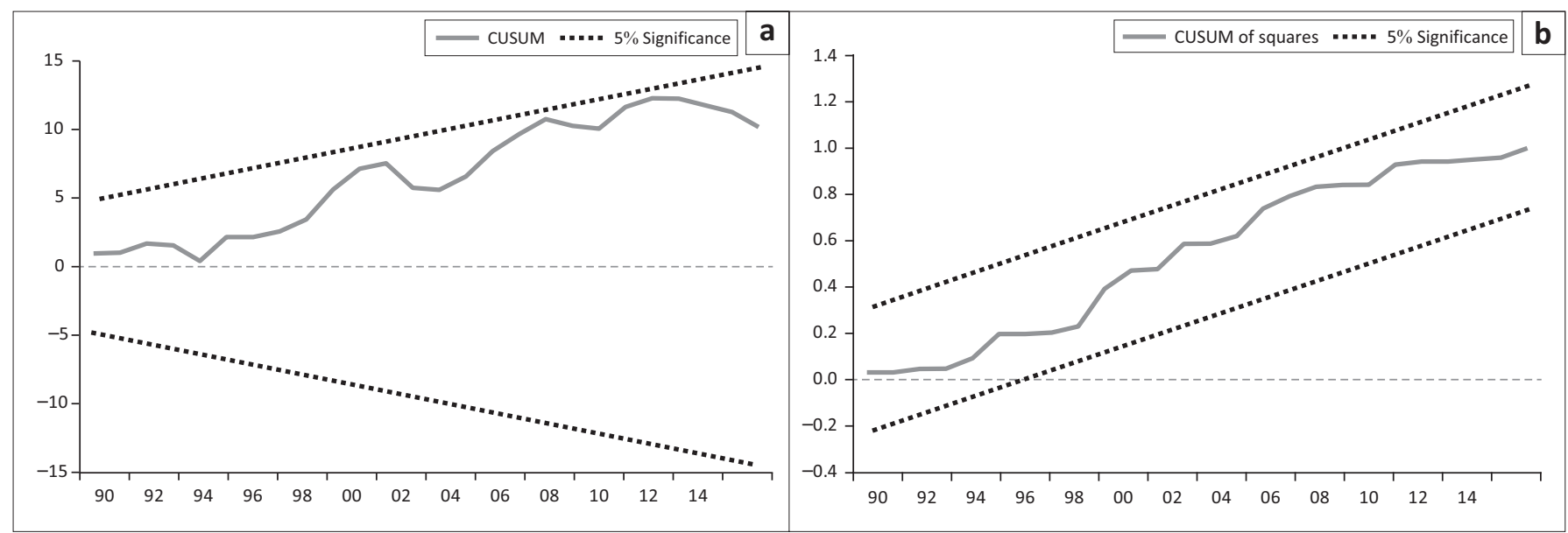

CUSUM, cumulative sum.

FIGURE 2: Stability Test - Cumulative sum and cumulative sum squared. (a) Plot of cumulative sum of recursive residuals. (b) Plot of cumulative sum of squares recursive residuals. 
equilibrium with the other variables in the previous period, it will adjust to restore equilibrium in the subsequent periods.

Lastly, the ARDL model passed all the diagnostic tests, as reported in Table 7 and Figure 2. These tests show that the model is correctly specified and parameter estimates are not biased. The cumulative sum squared (CUSUMQ) statistics lie within the $5 \%$ confidence interval, which suggests that the model parameter and variance are stable.

In order to test for robustness, the study used dummy variable (Tables 1-A1 and 2-A1, Appendix 1) and the same results were obtained. In the same way it means that the more the period of apartheid, the less the economic activity, as the apartheid period carries 1 .

\section{Conclusion and policy recommendations}

The objective of this study was to examine the effects of two major components of government expenditure on economic growth in South Africa. This study therefore contributes to the ongoing discourse in this regard. This study used annual data spanning over 42 years, and the ARDL and the error correction mechanism techniques were adopted. The control variables considered, guided by the literature, are categorised under labour, capital, institutional, macroeconomic and human capital variables.

Human capital was expected to be either positive or negative and was found to be negative and statistically significantly related to economic growth, both in the short and long runs. This supports the negative findings of Bittencourt et al. (2015). Seeing that unemployment in South Africa is structural, possible solutions could include on-the-job training, education reforms that can help to increase adult education and provision of vocational training, which provides the required skills needed for small and medium enterprises, thereby boosting the economic growth. The results further showed that in the short run, all the variables are highly statistically significant in determining the economic growth.

Given that the results depicted the positive effects of disaggregated government spending on economic growth, it showed the importance of government spending and how it could positively contribute to economic growth in the long run. Although this is contrary to some earlier studies, it is consistent with other studies, such as those by Ghosh and Gregorious (2008) on 15 developing countries and Ocran (2011) on South Africa, amongst others. The positive impact of government spending implies that it is not one of the factors that cause the negative or slow economic growth in South Africa. This is also in line with theoretical framework. The inefficiency normally associated with government spending cannot be ignored; however, the findings of this study showed that despite the misuse of funds by the government, there is still an element of positive effect of the spending on economic growth, especially in the long run This study therefore recommends that in the short run, government should endeavour to continue investing sensibly in order to benefit the economy in the long run. In the medium to long term, government should implement policies that will improve economic growth through skilled labour and increase GI spending.

In view of the fact that this study found a positive relationship between disaggregated government expenditure and economic growth in the short and long runs, whilst other studies carried out on South Africa found a negative relationship between aggregate government spending (and GC spending) and economic growth (Bittencourt et al. 2015; Chirwa \& Odhiambo 2016), this shows that GC expenditure outweighs and overshadows GI expenditure, as shown in Figure 1b. Also, as the results showed that GI has lower effects on economic growth, compared to GC, government should increase its efforts in investment expenditure as this positively impacts the economic growth both in the short and long runs. Better allocation of government spending is imperative and GC spending should thus be channelled to more productive activities.

Future research is needed to examine further disaggregated components of government spending and observe the effects of each on economic growth.

\section{Acknowledgements}

\section{Competing interests}

The author has declared that no competing interests exist.

\section{Authors' contributions}

I declare that I am the sole author of this research article.

\section{Funding information}

This research received no specific grant from any funding agency in the public, commercial or not-for-profit sectors.

\section{Data availability statement}

Data sharing is not applicable to this article as no new data were created or analysed in this study.

\section{Disclaimer}

The views and opinions expressed in this article are those of the author and do not necessarily reflect the official policy or position of any affiliated agency of the author.

\section{References}

Agell, J., Lindh, T. \& Ohlsson, H., 1997, 'Growth and the public sector: A critical review essay', European Journal of Political Economy 13(1), 33-52. https://doi. org/10.1016/S0176-2680(96)00031-6 
Akitoby, B., Clements, B., Gupta, S. \& Inchauste, G., 2006, 'Public spending, voracity, and Wagner's law in developing countries', European Journal of Political Economy 22(4), 908-924. https://doi.org/10.1016/j.ejpoleco.2005.12.001

Barro, R.J., 1989, A cross-country study of growth, saving, and government, National Bureau of Economic Research (NBER), Working Papers No. 2855.

Barro, R.J., 1990, 'Government spending in a simple model of endogenous growth model', Journal of Political Economy, 98(2), 103-125.

Barro, R.J., 1991, 'Economic growth in a cross section of countries', Quarterly Journa of Economics 106(2), 407-443. https://doi.org/10.2307/2937943

Barro, R.J., 1999, 'Determinants of economic growth: Implications of the global evidence for Chile', Cuademos de Economia 36(107), 443-478.

Barro, R.J., 2003, 'Determinants of economic growth in a panel of countries', Annals of Economics and Finance 4(2), 231-274.

Biswal, B., Dhawan, U. \& Lee, H.Y., 1999, 'Testing Wagner versus Keynes using disaggregated public expenditure data for Canada', Applied Economics 31(10), 1283-1291. https://doi.org/10.1080/000368499323490

Bittencourt, M., Van Eyden, R. \& Seleteng, M., 2015, 'Inflation and economic growth Evidence from the Southern African development community', South African Journal of Economics 83(3), 1-14. https://doi.org/10.1111/saje.12075

Blinder, A.S. \& Solow, R.M., 2005, 'Does fiscal policy matter?', In A. Bagchi, ed. Readings in Public Finance. New Delhi: Oxford University Press, pp. 283-300

Bose, N., Hague, M.E. \& Osborn, D.R., 2007, 'Public expenditure and economic growth: A disaggregated analysis for developing countries', The Manchester School 75(5), 533-556. https://doi.org/10.1111/j.1467-9957.2007.01028x

Checherita-Westphal, C. \& Rother, P., 2012, 'The impact of high government debt on economic growth and its channels: An empirical investigation for the Euro area European Economic Review 56(7), 1392-1405. https://doi.org/10.1016/j. euroecorev.2012.06.007

Chirwa, T.G. \& Odhiambo, N.M., 2016, 'What drives long run economic growth Empirical evidence from South Africa', International Economics 69(4), 425-452.

Christie, T., 2012, 'The effect of government spending on economic growth: Testing the non-linear hypothesis', Bulletin of Economic Research 66(2), 183-204. https:// doi.org/10.1111/j.1467-8586.2012.00438.x

D’Agostino, D., Dunne, J.P. \& Pieroni, L., 2012, Government spending, corruption and economic growth, Southern Africa Labour and Development Research Unit, Working Paper, Number 74, SALDRU, University of Cape Town, Cape Town.

Devarajan, S., Swaroop, V. \& Zou, H., 1996, 'The composition of public expenditure and economic growth', Journal of Monetary Economics 37(2), 313-344. https:// doi.org/10.1016/S0304-3932(96)90039-2

Easterly, W. \& Rebelo, S., 1993, 'Fiscal policy and economic growth: An empirical investigation', Journal of Monetary Economics 32(3), 417-458. https://doi. org/10.1016/0304-3932(93)90025-B

Ghosh, S. \& Gregorious, A., 2008, 'The composition of government spending and growth: Is current or capital spending better?', Oxford Economic Papers 60(3) 484-516. https://doi.org/10.1093/oep/gpn005

Hamilton, J.D. \& Monteagudo, J., 1998, 'The augmented Solow model and the productivity slowdown', Journal of Monetary Economics 42(3), 495-509. https:// productivity slowdown', Journal of Monetar
doi.org/10.1016/S0304-3932(98)00036-1

Heller, P., 2005, 'Back to basics-fiscal space: What it is and how to get it', Finance and Development 42(2), 32-33.

Iwegbunam, I.A., \& Robinson, Z., 2019, 'Economic growth models and government expenditure in South Africa: A disaggregated impact analysis', International Journal of Economics and Finance Studies 11(1), 33-48.

Keynes, J.M., 1936, The general theory of employment, interest, and money Macmillan, London.

Khan, M.S. \& Senhadji, A.S., 2001, Threshold effect in the relationship between inflation and growth, IMF Working Paper WP/00/110, International Monetary
Fund (IMF) Staff Papers, IMF Institute, viewed n.d., from https://www.imf.org/ Fund (IMF) Staff Papers, IMF Institute, vien
external/pubs/ft/wp/2000/wp00110.pdf

Leshoro, T.L., 2012, 'Estimating the inflation threshold for South Africa', Studies in Economics and Econometrics 36(2), 53-65.

Leshoro, T.L. \& Kollamparambil, U., 2017, 'Estimating a growth-maximising inflation targeting band for South Africa', International Journal of Economic Policy in Emerging Economies (IJEPEE) 10(4), 365-382. https://doi.org/10.1504/JJEPEE.2017.089163
Lucas, R.E., 1988, 'On the mechanics of economic development', Journal of Monetary Economics 22(1), 3-42. https://doi.org/10.1016/0304-3932(88)90168-7

Mincer, J., 1984, 'Human capital and economic growth', Economics of Education Review 3(3), 195-205. https://doi.org/10.1016/0272-7757(84)90032-3

Mo, P.H., 2007, 'Government expenditures and economic growth: The supply and demand sides', Fiscal Studies 28(4), 497-522. https://doi.org/10.1111/j.1475 5890.2007.00065.x

Mpatane, L.M. \& Eita, J.H., 2016, 'Manufactured exports and economic growth in Swaziland: Autoregressive Distributed Lag (ARDL) bound testing approach', GA International Academic Conferences Proceedings, New York, USA, 22nd-25th May 2016, pp. 272-280.

Ndambiri, H.K., Ritho, C., Ng'anga, S.I., Kubowon, P.C., Mairura, F.C. \& Nyangweso, P.M., 2012, 'Determinants of economic growth in sub-Saharan Africa: A panel data approach', International Journal of Economics and Management Sciences 2(2) $18-24$.

Ocran, M.K., 2011, 'Fiscal policy and economic growth in South Africa', Journal of Economic Studies 38(5), 604-618. https://doi.org/10.1108/01443581111161841

Odhiambo, N.M., 2015, 'Government Expenditure and Economic Growth in South Africa: An Empirical Investigation', Atlantic Economic Journal, 43, 393-406.

Oluwatobi, S.O. \& Ogunrinola, I.O., 2011, 'Government expenditure on human capital development: Implications for economic growth in Nigeria', Journal of Sustainable Development 4(3), 72-80. https://doi.org/10.5539/jsd.v4n3p72

Pesaran, M.H. \& Shin, Y., 1999, 'An autoregressive distributed lag modelling approach to cointegration analysis', in S. Strom (ed.), Chapter 11 in econometrics and economic theory in the 20th century, the Ragnar Frisch Centennial Symposium, Cambridge University Press, Cambridge, pp. 371-413. https://doi.org/10.1017/ CCOL521633230.011

Pesaran, M.H., Shin, Y. \& Smith, R.J., 2001, 'Bound testing approaches to the analysis of level relationships', Journal of Applied Econometrics 16(3), 289-326. https:// doi.org/10.1002/jae.616

Phiri, A., 2010, 'At what level is inflation least detrimental towards finance-growth activity in South Africa?', Journal of Sustainable Development in Africa 12(6), 354-364.

Radelet, S., Sachs, J. \& Lee, J., 2001, 'The determinants and prospects of economic growth in Asia', International Economic Journal 15(3), 1-29. https://doi. org/10.1080/10168730100080017

Ram, R., 1986, 'Government size and economic growth: A new framework and some evidence from cross-section and time-series data', American Economic Review 76(1), 191-203.

Romer, P.M., 1986, 'Increasing returns and long run growth', Journal of Political Economy 94(5), 1002-1037. https://doi.org/10.1086/261420

Schaltegger, C.A. \& Torgler, B., 2006, 'Growth effects of public expenditure on the state and local level: Evidence from a sample of rich government', Applied Economics 38(10), 1181-1192. https://doi.org/10.1080/00036840500392334

Setiloane, T., 2017, Beyond advocacy - Business needs to get its head in the game, McKinsey on Society, viewed 12 April 2017, from http://voices.mckinseyonsociety. com/south-africa-unemployment-in-youth/.

Solow, R.M., 1956, 'A contribution to the theory of economic growth', Quarterly Journal of Economics 70(1), 65-94. https://doi.org/10.2307/1884513

South African Reserve Bank (SARB), 2017, Quarterly bulletin, March No. 283. South African Reserve Bank, Pretoria.

South African Reserve Bank (SARB), 2019, Online database, viewed 13 March 2019, from https://www.resbank.co.za/Research/Statistics/Pages/OnlineDownloadFacility. aspx.

South African Reserve Bank (SARB), 2020, Economic and financial data for South Africa, viewed 07 July 2020, from https://wwwrs.resbank.co.za/webindicators/ EconFinDataForSA.aspx.

Statistics South Africa (STATSSA), 2018, Gross domestic product, second quarter 2018 Statistical Release, P0441, Pretoria.

Trading Economics, 2016, South Africa GDP annual growth rate, viewed 03 May 2016 , from http://www.tradingeconomics.com/south-africa/gdp-growth-annual.

The Global Economy, 2020, South Africa: Government spending, percent of GDP, viewed 03 Feb 2020, https://www.theglobaleconomy.com/South-Africa/ government_size/ 


\section{Appendix 1}

TABLE 1-A1: Correlation probability.

\begin{tabular}{|c|c|c|c|c|c|c|c|c|}
\hline Variable & $\log Y$ & $\log G F C F$ & logINF & $\log G C$ & $\log G I$ & $\log \mathrm{HC}$ & D_AP & POPG \\
\hline \multirow[t]{3}{*}{$\log Y$} & 1.000000 & - & - & - & - & - & - & - \\
\hline & - & - & - & - & - & - & - & - \\
\hline & - & - & - & - & - & - & - & - \\
\hline \multirow[t]{3}{*}{$\log G F C F$} & $0.918000 * * *$ & 1.000000 & - & - & - & - & - & - \\
\hline & 0.000000 & - & - & - & - & - & - & - \\
\hline & - & - & - & - & - & - & - & - \\
\hline & 0.000000 & 0.000000 & - & - & - & - & - & - \\
\hline & - & - & - & - & - & - & - & - \\
\hline \multirow[t]{3}{*}{$\log G C$} & $0.979000 * * *$ & $0.843000 * * *$ & $0.954000 * * *$ & 1.000000 & - & - & - & - \\
\hline & 0.000000 & 0.000000 & 0.000000 & - & - & - & - & - \\
\hline & - & - & - & - & - & - & - & - \\
\hline \multirow[t]{2}{*}{$\log G I$} & $0.374000 * *$ & $0.679000 * * *$ & 0.011000 & $0.252000 *$ & 1.000000 & - & - & - \\
\hline & 0.013500 & 0.000000 & 0.944200 & 0.102800 & - & - & - & - \\
\hline \multirow[t]{3}{*}{$\log H C$} & $0.446000 * * *$ & 0.235000 & $0.654000 * * *$ & $0.482000 * * *$ & $-0.331000 * *$ & 1.000000 & - & - \\
\hline & 0.002700 & 0.129600 & 0.000000 & 0.001100 & 0.030300 & - & - & - \\
\hline & - & - & - & - & - & - & - & - \\
\hline \multirow[t]{3}{*}{ D_AP } & $-0.813000 * * *$ & $-0.687000 * * *$ & $-0.866000 * * *$ & $-0.771000 * * *$ & -0.047000 & $-0.675000 * * *$ & 1.000000 & - \\
\hline & 0.000000 & 0.000000 & 0.000000 & 0.000000 & 0.765700 & 0.000000 & - & - \\
\hline & - & - & - & - & - & - & - & - \\
\hline \multirow[t]{2}{*}{ POPG } & $-0.910000 * * *$ & $-0.787000 * * *$ & $-0.908000 * * *$ & $-0.873000 * * *$ & -0.192000 & $-0.523000 * * *$ & $0.885000 * * *$ & 1.000000 \\
\hline & 0.000000 & 0.000000 & 0.000000 & 0.000000 & 0.216600 & 0.000300 & 0.000000 & - \\
\hline
\end{tabular}

$\mathrm{GC}$, government consumption; GI, government investment; POPG, population growth; HC, human capital; GFGC, gross fixed capital formation; INF, inflation.

$*, 10 \% ; * *, 5 \% ; * * *, 1 \%$.

TABLE 2-A1: Autoregressive distributed lag result - long-run and short-run estimates.

\begin{tabular}{|c|c|c|c|c|}
\hline Variable & Coefficient & Std. error & $t$-statistic & Prob. \\
\hline \multicolumn{5}{|c|}{ Cointegrating form } \\
\hline$\Delta \log (\mathrm{Y})_{t-1}$ & $-0.503 * * *$ & 0.152623 & -3.293237 & 0.0032 \\
\hline$\Delta \log (\mathrm{GFCF})$ & $0.134 * * *$ & 0.035644 & 3.770000 & 0.0010 \\
\hline$\Delta \log (\text { GFCF })_{t-1}$ & $0.112 * * *$ & 0.037490 & 2.975265 & 0.0068 \\
\hline$\Delta \log ($ INF) & $0.184^{*}$ & 0.091640 & 2.006503 & 0.0567 \\
\hline$\Delta \log (\text { INF })_{t-1}$ & $-0.371 * * *$ & 0.092500 & -4.013321 & 0.0005 \\
\hline$\Delta \log (\mathrm{GC})$ & $0.234 * * *$ & 0.066186 & 3.530642 & 0.0018 \\
\hline$\Delta \log (\mathrm{GI})$ & $0.164 * * *$ & 0.035887 & 4.581590 & 0.0001 \\
\hline$\Delta \log (\mathrm{GI})_{t-1}$ & $-0.056 * *$ & 0.026536 & -2.093920 & 0.0475 \\
\hline$\triangle(\mathrm{POPG})$ & $0.073 * * *$ & 0.032799 & 2.233334 & 0.0355 \\
\hline$\Delta \log (\mathrm{HC})$ & $-0.142 * * *$ & 0.038203 & -3.728757 & 0.0011 \\
\hline$\Delta\left(\mathrm{D} \_\mathrm{AP}\right)$ & $-0.023 * *$ & 0.010927 & -2.066729 & 0.0502 \\
\hline $\mathrm{ECT}_{t-1}$ & $-0.540 * * *$ & 0.080908 & -6.673083 & 0.0000 \\
\hline \multicolumn{5}{|c|}{ Long run coefficients } \\
\hline $\log (\mathrm{GFCF})_{t}$ & -0.063812 & 0.114200 & -0.558771 & 0.5817 \\
\hline $\log (\mathrm{INF})_{t}$ & 0.104039 & 0.064535 & 1.612129 & 0.1206 \\
\hline $\log (G C)_{t}$ & $0.363 * *$ & 0.162639 & 2.230532 & 0.0358 \\
\hline $\log (\mathrm{GI})_{t}$ & $0.226 * * *$ & 0.064867 & 3.487306 & 0.0020 \\
\hline $\mathrm{POPG}_{t}$ & -0.036737 & 0.034471 & -1.065717 & 0.2976 \\
\hline $\log (\mathrm{HC})_{t}$ & $-0.239 * *$ & 0.096009 & -2.489851 & 0.0204 \\
\hline D_AP & -0.085859 & 0.054556 & -1.573775 & 0.1292 \\
\hline$C_{t}$ & $23.729 * * *$ & 2.052888 & 11.558644 & 0.0000 \\
\hline
\end{tabular}

ECT, error correction term; GC, government consumption; GI, government investment; POPG, population growth; HC, human capital; GFCF, gross fixed capital formation; INF, inflation rate; $\mathrm{AP}$, apartheid period.

$*, 10 \% ; * *, 5 \%$; **, $1 \%$. 